\title{
Phytochemical screening and insecticidal activity of different extracts of Acacia modesta Wall. on adult Culex pipiens mosquito.
}

Eman Mohamed Salah' ${ }^{1}$, Reham R. Ibrahim ${ }^{2}$, Ahmed Hussien ${ }^{3}$, Khadega Salem ${ }^{4}$, Mariam H. Gonaid $^{1}$, Hesham S. M. Soliman ${ }^{2}$

${ }^{1}$ Faculty of Pharmaceutical sciences and Pharmaceutical Industries, Future University in

Egypt. ${ }^{2}$ Helwan University, Faculty of Pharmacy, Pharmacognosy Department, Cairo, ${ }^{3}$ Institute of

Medical Entomology, Ministry of Health, Giza, ${ }^{4}$ Research Institute of Ophthalmology. Corresponding author: Eman Mohamed Salah, Mobile phone: +01128266142,

E-mail: emanms4000@yahoo.com, emanms2000@gmail.com

\begin{abstract}
Background: Insect-transmitted diseases remain a major source of illness and death worldwide. Mosquitoes alone transmit diseases in more than 700 million people annually. The aim of the work: is to perform phytochemical screening tests and to investigate the insecticidal effects of different extracts of the aerial parts of Acacia modesta (A. modesta) Wall. on adult Culex pipiens (Cx. pipiens) mosquito. Materials and methods: Different $A$. modesta Wall. extracts were bioassayed against adult $C x$. Pipiens mosquito to estimate their insecticidal effects. Three different extracts of A. modesta Wall. aerial parts were prepared (distilled water, ethanol and acetone extracts). Different concentration for each prepared extract were tested for their insecticidal activity as well as different duration of exposure e.g. one hour, 24 hours, 48 hours and 72 hours were also performed. Results: The efficacy of these extracts varies according to type of solvent used, concentration of extract and duration of exposure. With continuous exposure for $24 \mathrm{hrs}$; efficacy of $A$. modesta Wall. extract was elevated from $62-91 \%$ in the same manner. Expanding the exposure for $48 \mathrm{hrs}$; show continuous elevation up to 90-100 \%. Meanwhile, the highest concentration of the tested plant extracted in acetone is one third $(100 \mathrm{mg} / \mathrm{ml})$ compared to other solvents $(300 \mathrm{mg} / \mathrm{ml})$, results showed that using acetone as a solvent is better than either distilled water or ethanol for its insecticidal activity. Conclusion: It was evident from the results that the plant is a potential source of botanical insecticides against adult $C x$. pipiens mosquitoes and their toxic effects are time and concentration dependent. Moreover, phytochemical screening for the aerial parts of $A$. modesta Wall. resulted in the identification of carbohydrates and/or glycosides, tannins, flavonoids, unsaturated sterols and/or triterpens as well as saponins.
\end{abstract}

Keywords: Acacia modesta Wall., Culex pipiens, insecticides and phytochemical screening.

\section{Introduction:}

Insect-transmitted diseases remain a major source of illness and death worldwide. Mosquitoes alone transmit diseases in more than 700 million people annually ${ }^{1}$.

Control of such diseases is becoming increasingly difficult because the over production of detoxifying mechanisms of resistance of chemical insecticides has reported for most mosquito species. On the other hand, majority of mosquito species have also developed high levels of resistance to microbial control agents. One alternative control approach is the use of natural insecticides from plant origin.

The botanical insecticides are generally pest specific and are relatively harmless to the nontarget organisms including $\operatorname{man}^{2}$. They are also biodegradable and harmless to environment. One plant species may possess chemical substances with a wide range of activities, like extracts from Azadriachta indica which showed

antifeedent, antioviposition, repellent and growth regulating activity ${ }^{2}$.

A. modesta, commonly known as Phulai, is a member of the family Fabaceae (also called Leguminosae) and sub-family Mimosaceae. It is a deciduous, slow-growing small tree with thorny youngshoots and dark brown and black wood, reaching 7 meters height and $20 \mathrm{~cm}$ diameter ${ }^{3}$.

Reports on A. modesta aerial parts exposed the presence of flavonoids, alkaloids, terpenoids and tannins and long chain alcohols ${ }^{4}$. The aim of the current study is to perform phytochemical screening tests and to investigate the insecticidal effects of different extracts of the aerial parts of A. modesta Wall. on adult $C x$. pipiens mosquito

\section{Materials and methods}


Insecticidal activity:

Plant materials: Collection and preservation of the plant:

The aerial parts of A. modesta Wall. were collected in August 2015 from Giza zoo garden, the plant was kindly identified and authenticated by taxonomist Dr. Threse Labib consultant in the central gardening administration, Orman garden, Giza, Egypt. Voucher specimens had been deposited in the Pharmacognosy Department, Faulty of Pharmacy, Future University In Egypt, Cairo, Egypt.

\section{Preparation of the extract:}

90 grams of the air dried powder aerial parts of A. modesta Wall. were used in this experiment, each extract was achieved by soaking the ground plant material with the solvent for 48 hours then filtered withstandard filter paper. 30 $\mathrm{g}$ of the aerial parts was extracted with distilled water, another $30 \mathrm{~g}$ of the aerial parts was extracted with ethanol alcohol, the remaining $30 \mathrm{~g}$ of the aerial parts was extracted withacetone. Extracts were dried using rotary evaporator R-3 ( Buchi, A.G., Switzerland).

Bioassays requirements: The insecticidalbioassays activities were carried out at the Institute of Medical Entomology, Ministry of health, Giza, Egypt.

The insecticidal activity of the extracts was conducted using modified CDC bottle assay. 250-ml Wheaton bottles with screw lids. Each bioassay concentration typically requires five bottles: four for replicates and one for control, graduated disposable plastic pipettes that can measure $1 \mathrm{ml}$, or micropipettes and tips, aspirator apparatus for collecting mosquitoes, containers for transferring/holding mosquitoes, bottles for concentrate solutions, timer capable of counting seconds, permanent markers for labeling bottles, caps, pipettes, masking tape for labeling bottles, caps, and pipettes, disposable gloves; Sheets, pens, and pencils for data recording.

\section{Procedure:}

Every sample bottled in the corresponding bottle and covered, rotation, and gentle shaking of the bottles takes place to ensure adequate layering of the sample to the inside wall of each bottle. Dryness of the bottle is helped by use of electric incubator at $35^{\circ} \mathrm{Cwhile}$ the cap was removed with frequent rotation to ensure homogenous film layering of the sample.After complete dryness of the sample, the bottles stored with loss cap tighten in the dark dry places for 24 hours to ensure complete dryness. Test was done in at least two replicate for tested concentrates, solvent control, and counter tested chemical insecticide.

Adult female non-blood feed $C x$. pipiens mosquito of the same progeny group $(20-40$ in number) is delivered to every tested and control bottle for one hour exposure, 24, 48 and 72 hours for distilled water and ethanol extract, and for one hour, 24, and 48 hours for the acetone extract.Knockdown of the insects were followed up during exposure time every $10 \mathrm{~min}$. (insect fall to the bottom or on its back or that one cannot move), and mortality calculated against time. The mortality rates were counted for: Test concentrates (different one), test solvent (test control distilled water, ethanol and acetone), pesticide control (ethanol) and standardized synthetic Pesticide (deltamethrine) as comparative mean. The mean for replicates is then plotted against time. Temperature and relative humidity were recorded at the beginning and end of the test. Results would be accepted for control bottle when mortalities were less than $5 \%$ percent (distilled water, ethanol and acetone), and rejected when the mortality rate was more than $20 \%$ percent. Five different concentrations were used for distilled water and ethanol extracts $(300,200,100,50$ and $25 \mathrm{mg} / \mathrm{ml})$ of $A$ .modesta Wall. . The concentration of deltamethrine used in the experiment was $(0.125 \mathrm{mg} / \mathrm{ml})$ dissolved in ethanol. The solvent used (distilled water, ethanol and acetone; El Nasr Com., Cairo, Egypt). For the diethyl ether residue four different concentrations were used $(100,50,25,12.5 \mathrm{mg} / \mathrm{ml}$ of $A$.modesta Wall)

\section{Phytochemical screening:}

\section{Preparation of the extract:}

Twenty grams of A. modesta Wall. aerial parts were macerated in $70 \%$ methyl alcohol, filtered and kept in amber colored bottles for screening.

\section{Procedure:}

The total extract was screened via different phytochemical screening tests ${ }^{5-14}$.

\section{Statistical analysis}


Phytochemical screening and insecticidal activity of different extracts of Acacia modesta Wall...

The collected data were analyzed using the statistical analysis system SAS software package (version 9.0). Data were presented using frequency number and percent and mean $\pm \mathrm{SD}$ as appropriate. Chi square test was used as appropriate, $\mathrm{p}$ value $<0.05$ were used as indicators of statistical significant difference.

\section{Results: The insecticidal activity:}

Table (1) Effect of different concentrations of distilled water extract of Acacia modesta Wall. aerial parts on adult Culex pipiens mosquitoes after exposure for one hour.

\begin{tabular}{|c|c|c|c|c|c|c|c|}
\hline \multirow[b]{2}{*}{ Concentrations } & \multirow{2}{*}{$\begin{array}{l}\text { Number of } \\
\text { introduced } \\
\text { mosquitos }\end{array}$} & \multicolumn{4}{|c|}{ Effect of one hour exposure } & \multicolumn{2}{|c|}{ Statistical analysis } \\
\hline & & $\begin{array}{c}\text { Living } \\
\text { No. }\end{array}$ & $\begin{array}{c}\text { Living } \\
\%\end{array}$ & $\begin{array}{l}\text { Dead } \\
\text { No. }\end{array}$ & Mortality \% & $\chi^{2}$ & $\mathrm{P}$ \\
\hline $300 \mathrm{mg} / \mathrm{ml}$ & 32 & 32 & 100 & 0 & 0 & \multirow[t]{8}{*}{225.96} & \multirow[t]{8}{*}{$\mathrm{P}<0.0005$} \\
\hline $200 \mathrm{mg} / \mathrm{ml}$ & 33 & 33 & 100 & 0 & 0 & & \\
\hline $100 \mathrm{mg} / \mathrm{ml}$ & 32 & 32 & 100 & 0 & 0 & & \\
\hline $50 \mathrm{mg} / \mathrm{ml}$ & 28 & 28 & 100 & 0 & 0 & & \\
\hline $25 \mathrm{mg} / \mathrm{ml}$ & 30 & 30 & 100 & 0 & 0 & & \\
\hline $\begin{array}{c}\text { Distilled } \\
\text { Water }\end{array}$ & 33 & 33 & 100.0 & 0 & 0 & & \\
\hline Deltamethrine & 40 & 5 & 12.5 & 35 & 87.5 & & \\
\hline Ethanol & 36 & 36 & 100 & 0 & 0 & & \\
\hline
\end{tabular}

No.; Number, \% percentage, chi-square $\chi^{2}=225.96$ and probability value $\mathrm{P}<0.0005$.

Table (1) shows that after one hour there were no effect of different concentrations of distilled water extract of the studied plant as well as the control on adult $C x$. pipiens mosquitoes compared with the standard Deltamethrine (mortality rate was $87.5 \%$ ).

Table (2) Effect of different concentrations of ethanol extract of Acacia modesta Wall. aerial parts on adult Culex pipiens mosquitoes after exposure for one hour.

\begin{tabular}{|c|c|c|c|c|c|c|c|}
\hline \multirow[b]{2}{*}{ Concentrations } & \multirow{2}{*}{$\begin{array}{l}\text { Number of } \\
\text { introduced } \\
\text { mosquitos }\end{array}$} & \multicolumn{4}{|c|}{ Effect of one hour exposure } & \multicolumn{2}{|c|}{ Statistical analysis } \\
\hline & & $\begin{array}{l}\text { Living } \\
\text { No. }\end{array}$ & $\begin{array}{c}\text { Living } \\
\%\end{array}$ & $\begin{array}{l}\text { Dead } \\
\text { No. }\end{array}$ & $\begin{array}{c}\text { Mortality } \\
\%\end{array}$ & $\chi^{2}$ & $\mathrm{P}$ \\
\hline $300 \mathrm{mg} / \mathrm{ml}$ & 32 & 32 & 100 & 0 & 0 & \multirow{7}{*}{189.06} & \multirow{7}{*}{$\mathrm{P}<0.0005$} \\
\hline $200 \mathrm{mg} / \mathrm{ml}$ & 27 & 27 & 100 & 0 & 0 & & \\
\hline $100 \mathrm{mg} / \mathrm{ml}$ & 29 & 29 & 100 & 0 & 0 & & \\
\hline $50 \mathrm{mg} / \mathrm{ml}$ & 28 & 28 & 100 & 0 & 0 & & \\
\hline $25 \mathrm{mg} / \mathrm{ml}$ & 30 & 30 & 100 & 0 & 0 & & \\
\hline Deltamethrine & 40 & 5 & 12.5 & 35 & 87.5 & & \\
\hline Ethanol & 36 & 36 & 100 & 0 & 0 & & \\
\hline
\end{tabular}

No.; Number, $\%$ percentage, chi-square $\chi^{2}=189.06$ and probability value $\mathrm{P}<0.0005$.

Table (2) shows that after one hour, there were no effect of different concentrations of ethanol extract of the studied plant as well as the control on adult Cx. pipiens mosquitoes compared to the standard of Deltamethrine (mortality rate was $87.5 \%$ ).

Table (3) Effect ofdifferent concentrations of distilled water extract of Acacia modesta Wall. aerial parts on adult Culex pipiens mosquitoes and control after continuous exposure for 24 hours. 


\begin{tabular}{|c|c|c|c|c|c|c|c|}
\hline \multirow{2}{*}{ Concentrations } & \multirow{2}{*}{$\begin{array}{l}\text { Number of } \\
\text { introduced } \\
\text { mosquitos }\end{array}$} & \multicolumn{4}{|c|}{ Effect of 24 hours exposure } & \multicolumn{2}{|c|}{ Statistical analysis } \\
\hline & & $\begin{array}{c}\text { Living } \\
\text { No. }\end{array}$ & Living \% & $\begin{array}{c}\text { Dead } \\
\text { No. }\end{array}$ & Mortality \% & $\chi^{2}$ & $\mathrm{P}$ \\
\hline $300 \mathrm{mg} / \mathrm{ml}$ & 33 & 20 & 60.6 & 13 & 39.4 & \multirow{6}{*}{14.79} & \multirow{6}{*}{$\mathrm{P}<0.05$} \\
\hline $200 \mathrm{mg} / \mathrm{ml}$ & 31 & 22 & 71 & 9 & 29 & & \\
\hline $100 \mathrm{mg} / \mathrm{ml}$ & 31 & 24 & 77.4 & 7 & 22.6 & & \\
\hline $50 \mathrm{mg} / \mathrm{ml}$ & 40 & 32 & 80 & 8 & 20 & & \\
\hline $25 \mathrm{mg} / \mathrm{ml}$ & 36 & 29 & 80.6 & 7 & 19.4 & & \\
\hline Distilled water & 28 & 28 & 100 & 0 & 0 & & \\
\hline
\end{tabular}

No.; Number, $\%$ percentage, chi-square $\chi^{2}=14.79$ and probability value $\mathrm{P}<0.05$.

Table (3) shows that after 24 hours exposure ofmosquitoes to different concentrations of distilled water extract the mortality rates ranged from $19.4-39.4 \%$. The highest percentage of mortality was found to be at concentration $300 \mathrm{mg} / \mathrm{ml}(39.4 \%)$, the insecticidal activity (\% mortality) ranging from $19.4-39.4 \%$, it is a function of increasing concentration.

Table (4) Effect of different concentrations of ethanol extract of Acacia modesta Wall .aerial parts on adult Culex pipiens mosquitoes and control group after continuous exposure for 24 hours.

\begin{tabular}{|c|c|c|c|c|c|c|c|}
\hline \multirow[b]{2}{*}{ Concentrations } & \multirow{2}{*}{$\begin{array}{l}\text { Number of } \\
\text { introduced } \\
\text { mosquitos }\end{array}$} & \multicolumn{4}{|c|}{ Effect of 24 hours exposure } & \multicolumn{2}{|c|}{ Statistical analysis } \\
\hline & & $\begin{array}{c}\text { Living } \\
\text { No. }\end{array}$ & $\begin{array}{c}\text { Living } \\
\%\end{array}$ & $\begin{array}{l}\text { Dead } \\
\text { No. }\end{array}$ & $\begin{array}{c}\text { Mortality } \\
\%\end{array}$ & $\overline{\chi^{2}}$ & $\bar{P}$ \\
\hline $300 \mathrm{mg} / \mathrm{ml}$ & 35 & 6 & 17.1 & 29 & 82.9 & \multirow{6}{*}{78.98} & \multirow{6}{*}{$\mathrm{P}<0.0005$} \\
\hline $200 \mathrm{mg} / \mathrm{ml}$ & 33 & 8 & 24.2 & 25 & 75.7 & & \\
\hline $100 \mathrm{mg} / \mathrm{ml}$ & 31 & 12 & 38.7 & 19 & 61.3 & & \\
\hline $50 \mathrm{mg} / \mathrm{ml}$ & 33 & 23 & 69.7 & 10 & 30.3 & & \\
\hline $25 \mathrm{mg} / \mathrm{ml}$ & 22 & 19 & 86.4 & 3 & 13.6 & & \\
\hline Ethanol & 38 & 38 & 100 & 0 & 0 & & \\
\hline
\end{tabular}

No.; Number, \% percentage, chi-square $\chi^{2}=78.98$ and probability value $\mathrm{P}<0.0005$.

Table (4) shows that after 24 hours exposure to different concentrations of the ethanol extract of the studied plant, percentage of mortality of mosquitoes ranged from (13.6-83\%). The highest effect (83\%), was due to exposure to the highest concentration $(300 \mathrm{mg} / \mathrm{ml})$.

Table (5) Effect ofdifferent concentrations of distilled water extract of Acacia modesta Wall. aerial parts on adult Culex pipiens mosquitoes and control after continuous exposure for 48 hours.

\begin{tabular}{|c|c|c|c|c|c|c|c|}
\hline \multirow{2}{*}{ Concentrations } & \multirow{2}{*}{$\begin{array}{l}\text { Number of } \\
\text { introduced } \\
\text { mosquitos }\end{array}$} & \multicolumn{4}{|c|}{ Effect of 48 hours exposure } & \multicolumn{2}{|c|}{ Statistical analysis } \\
\hline & & $\begin{array}{l}\text { Living } \\
\text { No. }\end{array}$ & $\begin{array}{c}\text { Living } \\
\%\end{array}$ & $\begin{array}{l}\text { Dead } \\
\text { No. }\end{array}$ & $\begin{array}{c}\text { Mortality } \\
\%\end{array}$ & $\chi^{2}$ & $\mathrm{P}$ \\
\hline $300 \mathrm{mg} / \mathrm{ml}$ & 33 & 0 & 6 & 33 & 100 & \multirow{6}{*}{102.09} & \multirow{6}{*}{$\mathrm{P}<0.0005$} \\
\hline $200 \mathrm{mg} / \mathrm{ml}$ & 31 & 2 & 6.5 & 29 & 93.5 & & \\
\hline $100 \mathrm{mg} / \mathrm{ml}$ & 31 & 3 & 9.7 & 28 & 90.3 & & \\
\hline $50 \mathrm{mg} / \mathrm{ml}$ & 40 & 4 & 10 & 36 & 90 & & \\
\hline $25 \mathrm{mg} / \mathrm{ml}$ & 36 & 3 & 8.3 & 33 & 91.7 & & \\
\hline Distilled water & 28 & 24 & 85.7 & 4 & 14.3 & & \\
\hline
\end{tabular}

No.; Number, \% percentage, chi-square $\chi^{2}=102.09$ and probability value $\mathrm{P}<0.0005$

Table (5) shows that after 48 hours exposure of mosquitoes to different concentrations of the plant in distilled water the mortality rates ranged from $90-100 \%$. The highest rate was in concentration 300 $\mathrm{mg} / \mathrm{ml}(100 \%)$. The difference of mortality was highly statistically significant.

Table (6) Effect of different concentrations of ethanol extract of Acacia modesta Wall. aerial parts on adult Culex pipiens mosquitoes and control group after continuous exposure for 48 hours. 
Phytochemical screening and insecticidal activity of different extracts of Acacia modesta Wall...

\begin{tabular}{|c|c|c|c|c|c|c|c|}
\hline \multirow{2}{*}{ Concentrations } & \multirow{2}{*}{$\begin{array}{l}\text { Number of } \\
\text { introduced } \\
\text { mosquitos }\end{array}$} & \multicolumn{4}{|c|}{ Effect of 48 hours exposure } & \multicolumn{2}{|c|}{ Statistical analysis } \\
\hline & & $\begin{array}{l}\text { Living } \\
\text { No. }\end{array}$ & $\begin{array}{c}\text { Living } \\
\%\end{array}$ & $\begin{array}{l}\text { Dead } \\
\text { No. }\end{array}$ & $\begin{array}{c}\text { Mortality } \\
\%\end{array}$ & $\chi^{2}$ & $\mathrm{P}$ \\
\hline $300 \mathrm{mg} / \mathrm{ml}$ & 35 & 2 & 5.7 & 33 & 94.3 & \multirow{6}{*}{95.21} & \multirow{6}{*}{$\mathrm{P}<0.0005$} \\
\hline $200 \mathrm{mg} / \mathrm{ml}$ & 33 & 3 & 9.1 & 30 & 90.9 & & \\
\hline $100 \mathrm{mg} / \mathrm{ml}$ & 31 & 10 & 32.3 & 21 & 67.7 & & \\
\hline $50 \mathrm{mg} / \mathrm{ml}$ & 33 & 23 & 69.7 & 10 & 30.3 & & \\
\hline $25 \mathrm{mg} / \mathrm{ml}$ & 22 & 15 & 53.3 & 7 & 46.7 & & \\
\hline Ethanol & 38 & 37 & 97.3 & 1 & 2.7 & & \\
\hline
\end{tabular}

No.; Number, $\%$ percentage, chi-square $\chi^{2}=95.21$ and probability value $\mathrm{P}<0.0005$

Table (6) shows that after 48 hours exposure to different concentrations of the ethanol extract of the studied plant, mortality rates of mosquitoes ranged from (47-94.3\%). The highest effect (94.3\%) was due to exposure to concentration $(300 \mathrm{mg} / \mathrm{ml})$.

Table (7) Effect of different concentrations of Acacia modesta Wall. aerial parts ethanol extract on adult Culex pipiens mosquitoes and control group after continuous exposure 72 hours.

\begin{tabular}{|c|c|c|c|c|c|c|c|}
\hline \multirow{2}{*}{ Concentrations } & \multirow{2}{*}{$\begin{array}{l}\text { Number of } \\
\text { introduced } \\
\text { mosquitos }\end{array}$} & \multicolumn{4}{|c|}{ Effect of 72 hours exposure } & \multicolumn{2}{|c|}{ Statistical analysis } \\
\hline & & $\begin{array}{c}\text { Living } \\
\text { No. }\end{array}$ & Living \% & $\begin{array}{l}\text { Dead } \\
\text { No. }\end{array}$ & $\begin{array}{c}\text { Mortality } \\
\%\end{array}$ & $\chi^{2}$ & $\mathrm{P}$ \\
\hline $300 \mathrm{mg} / \mathrm{ml}$ & 35 & 0 & 0 & 35 & 100.0 & \multirow{6}{*}{80.25} & \multirow{6}{*}{$\mathrm{P}<0.0005$} \\
\hline $200 \mathrm{mg} / \mathrm{ml}$ & 33 & 2 & 6.1 & 31 & 93.9 & & \\
\hline $100 \mathrm{mg} / \mathrm{ml}$ & 31 & 11 & 35.5 & 20 & 64.5 & & \\
\hline $50 \mathrm{mg} / \mathrm{ml}$ & 33 & 13 & 39.4 & 20 & 60.6 & & \\
\hline $25 \mathrm{mg} / \mathrm{ml}$ & 22 & 10 & 45.5 & 12 & 54.5 & & \\
\hline Ethanol & 38 & 34 & 89.5 & 4 & 10.5 & & \\
\hline
\end{tabular}

No.; Number, $\%$ percentage, chi-square $\chi^{2}=80.25$ and probability value $\mathrm{P}<0.0005$.

Table (7) indicates that aftercontinuous exposure for 72 hours to the ethanol extract of A. modesta aerial parts. The mortality rates of mosquitoes ranged from $(54.5-100 \%)$. The highest effect was due to concentration $(300 \mathrm{mg} / \mathrm{ml})(100 \%)$.

Table (8) Effect of extract of different concentrations of Acacia modesta Wall. aerial parts acetone extract on adult Culex pipiens mosquitoes and acetone after one-hour exposure.

\begin{tabular}{|c|c|c|c|c|c|c|c|}
\hline \multirow[b]{2}{*}{ Concentrations } & \multirow[b]{2}{*}{$\begin{array}{c}\text { Number of } \\
\text { introduced } \\
\text { mosquitos }\end{array}$} & \multicolumn{4}{|c|}{ Effect of one hour exposure } & \multicolumn{2}{|c|}{ Statistical analysis } \\
\hline & & $\begin{array}{c}\text { Living } \\
\text { No. }\end{array}$ & Living \% & $\begin{array}{l}\text { Dead } \\
\text { No. }\end{array}$ & $\begin{array}{c}\text { Mortality } \\
\%\end{array}$ & $\chi^{2}$ & $\mathrm{P}$ \\
\hline $100 \mathrm{mg} / \mathrm{ml}$ & 33 & 13 & 39.4 & 20 & 60.6 & \multirow{5}{*}{16.14} & \multirow{5}{*}{$\mathrm{P}<0.01$} \\
\hline $50 \mathrm{mg} / \mathrm{ml}$ & 30 & 13 & 43.3 & 17 & 56.7 & & \\
\hline $25 \mathrm{mg} / \mathrm{ml}$ & 39 & 25 & 64.1 & 14 & 35.9 & & \\
\hline $12.5 \mathrm{mg} / \mathrm{ml}$ & 21 & 15 & 71.4 & 6 & 28.6 & & \\
\hline Acetone & 21 & 18 & 85.7 & 3 & 14.3 & & \\
\hline
\end{tabular}

No.; Number, $\%$ percentage, chi-square $\chi^{2}=16.14$ and probability valueP $<0.01$

After one-hour exposure to the extract of A. modesta Wall. aerial parts in acetone, table (8) shows good effectiveness of the plant extract on adult $C x$. pipiens mosquitoes the (mortality rates of mosquitoes ranged from $28.6-60.6 \%$ ) compared with control. The difference is statistically significant. The highest effect was due to concentration $(100 \mathrm{mg} / \mathrm{ml})(60.6 \%)$.

Table (9) Effect of different concentrations of Acacia modesta Wall. aerial parts acetone extract on adult Culex pipiens mosquitoes and acetone after 24 hours exposure. 


\begin{tabular}{|c|c|c|c|c|c|c|c|}
\hline \multirow{2}{*}{ Concentrations } & \multirow{2}{*}{$\begin{array}{l}\text { Number of } \\
\text { introduced } \\
\text { mosquitos }\end{array}$} & \multicolumn{4}{|c|}{ Effect of 24 hours exposure } & \multicolumn{2}{|c|}{ Statistical analysis } \\
\hline & & $\begin{array}{l}\text { Living } \\
\text { No. }\end{array}$ & Living $\%$ & $\begin{array}{l}\text { Dead } \\
\text { No. }\end{array}$ & $\begin{array}{c}\text { Mortality } \\
\%\end{array}$ & $\chi^{2}$ & $\mathrm{P}$ \\
\hline $100 \mathrm{mg} / \mathrm{ml}$ & 33 & 3 & 9.1 & 30 & 90.9 & \multirow{5}{*}{42.8} & \multirow{5}{*}{$\mathrm{P}<0.0005$} \\
\hline $50 \mathrm{mg} / \mathrm{ml}$ & 30 & 8 & 26.7 & 22 & 73.3 & & \\
\hline $25 \mathrm{mg} / \mathrm{ml}$ & 39 & 6 & 15.4 & 33 & 84.6 & & \\
\hline $12.5 \mathrm{mg} / \mathrm{ml}$ & 21 & 8 & 38.1 & 13 & 61.9 & & \\
\hline Acetone & 21 & 18 & 85.7 & 3 & 14.3 & & \\
\hline
\end{tabular}

No.; Number, \% percentage, chi-square $\chi^{2}=42.8$ and probability value $\mathrm{P}<0.0005$

Table (9) shows that after 24 hours exposure to the extract of $A$. modesta plants in acetone, high effect of the plant extract on adult $C x$. pipiens mosquitoes (the mortality rates of mosquitoes ranged from 62$91 \%$ ) compared with control.

The mortality percentages difference isstatistically significant. The highest effect was due to concentration $(300 \mathrm{mg} / \mathrm{ml})(91 \%)$.

Table (10) Effectof different concentrations of Acacia modesta Wall. aerial parts acetone extract on adult Culex pipiens mosquitoes and acetone after exposure for 48 hours.

\begin{tabular}{|c|c|c|c|c|c|c|c|}
\hline \multirow{2}{*}{ Concentrations } & \multirow{2}{*}{$\begin{array}{l}\text { Number of } \\
\text { introduced } \\
\text { mosquitos }\end{array}$} & \multicolumn{4}{|c|}{ Effect of one 48 hours exposure } & \multicolumn{2}{|c|}{ Statistical analysis } \\
\hline & & $\begin{array}{c}\text { Living } \\
\text { No. }\end{array}$ & Living \% & $\begin{array}{l}\text { Dead } \\
\text { No. }\end{array}$ & $\begin{array}{c}\text { Mortality } \\
\%\end{array}$ & $\chi^{2}$ & $\mathrm{P}$ \\
\hline $100 \mathrm{mg} / \mathrm{ml}$ & 30 & 0 & 0 & 30 & 100 & \multirow{5}{*}{120.49} & \multirow{5}{*}{$\mathrm{P}<0.0005$} \\
\hline $50 \mathrm{mg} / \mathrm{ml}$ & 33 & 0 & 0 & 33 & 100 & & \\
\hline $25 \mathrm{mg} / \mathrm{ml}$ & 39 & 0 & 0 & 39 & 100 & & \\
\hline $12.5 \mathrm{mg} / \mathrm{ml}$ & 21 & 0 & 0 & 21 & 100 & & \\
\hline Acetone & 21 & 18 & 85.7 & 3 & 14.3 & & \\
\hline
\end{tabular}

No.; Number, \% percentage, chi-square $\chi^{2}=120.49$ and probability value $\mathrm{P}<0.0005$.

Table (10) declared that after 48 hours exposure to the extract of A. modesta Wall. plant in acetone, the best effect occurs in all concentrations(the mortality rates of mosquitoes were $100 \%$ ).

\section{Phytochemical screening:}

Table (11): Results of the phytochemical screening tests for Acacia modesta Wall. aerial parts.

\begin{tabular}{|c|c|c|c|}
\hline Active constituents & Result & Test & Reference \\
\hline $\begin{array}{c}\text { Carbohydrates and/or } \\
\text { glycosides }\end{array}$ & $+\mathrm{ve}$ & Molish test & 5 \\
\hline Tannins & $+\mathrm{ve}$ & Ferric chloride test & 6 \\
\hline Flavonoids & $+\mathrm{ve}$ & Schinoda's test & $8-9$ \\
\hline $\begin{array}{c}\text { Unsaturated sterols } \\
\text { and/or triterpens }\end{array}$ & $+\mathrm{ve}$ & Lieberman-Burchared's test & Salkoweski's test \\
\hline $\begin{array}{c}\text { Saponins } \\
\text { glycosides }\end{array}$ & $+\mathrm{ve}$ & Froth test & 10 \\
\hline $\begin{array}{c}\text { Alkaloids } \\
\text { Anthraquinone }\end{array}$ & $-\mathrm{ve}$ & Borntrager's test and modified Borntrager's tests & $11-12$ \\
\hline
\end{tabular}

+ve; positive, -ve; negative

Table (11) Illustrated results of phytochemical screening of A. modesta wall. aerial parts. It revealed the presence of the carbohydrates and/or glycosides, tannins ,flavonoids , unsaturated sterols and/or triterpens as well as 
saponins meanwhile the absence of Anthraquinone glycosides as well as alkaloids.

\section{Discussion}

Synthetic chemical pesticides have some serious flaws to environmental and health related concerns. It is expected that only in America about 200 people are dying every year due to this pesticidal poisoning ${ }^{15}$. These problems resulted in renewed interest in formulating new botanical pesticides, which could be nonhazardous, effective, biodegradable, and of low cost and pose less threat to the environment ${ }^{16}$.

Chemical pesticides have shown very good results at the beginning, but with the passage of time, the need was realized to use the natural plant sources for the safe control of insects. The current study will provide minor contribution towards it. The aim of the present study was to evaluate the insecticidal activities of different concentrations of A. modesta Wall. extracts in many solvents such as distilled water, ethanol and acetone to detect the suitable solvent as well as concentrations

Results of this study showed that exposure of the adult $C x$. pipiens mosquitoes to the cold extract of different concentrations A. modesta Wall. aerial parts extracted with distilled water as well as those dissolved in ethanol has no significant effect on $\mathrm{Cx}$. pipiens mosquitoes after exposure for one hour meanwhile the exposure to the plant extracted with acetone for the same period have induced mortalities among exposed insects, (mortality rates of mosquitoes ranged from 28.6-60.6\%). The highestmortality rate was due toconcentration $(300 \mathrm{mg} / \mathrm{ml}) 61 \%$. Increasing duration of exposure also was in favor of the plant dissolved in acetone. The mortality rates of mosquitoesafter 24 hours of exposure ranged from $62-91 \%$ compared with control. The difference is statistically significant. The highest effect was due to concentration (300 $\mathrm{mg} / \mathrm{ml})(91 \%)$. meanwhile the exposure to the ethanol extract for the same period ( 24 hours) have induced lower mortalities among exposed insects, (mortality rates of mosquitoes ranged from 13.6-83\%) and alsothe exposure to the distilled water extract for the same period have induced the lowest mortalities among exposed insects, (mortality rates of mosquitoes ranged from 19.4-39.4\%),

In addition, after continuous exposure for 48 hours of all concentrations of the acetone extract, the percentage of mortality of mosquitoes were $100 \%$ in all concentrations. Meanwhile, the exposure to the ethanol extract for the same period of time had induced lower mortalities among exposed insects, ( mortality rates of mosquitoes ranged from 47-94.3\%), and also the exposure to the distilled water extract for the same period have led to lower mortalities among exposed insects, ( mortality rates of mosquitoes ranged from $90-100 \%$ ).

Although, the highest concentration of the tested plant extracted in acetone was onethird $(100 \mathrm{mg} / \mathrm{ml})$ compared to other solvents $(300 \mathrm{mg} / \mathrm{ml})$, results showed that using acetone as a solvent was most effective than either distilled water or ethanol for its insecticidal activity. Similar results were obtained by Nazeefullah $\boldsymbol{e t} \boldsymbol{a l} .{ }^{17}$ using different cold water extracts dilutions of $A$. modesta when tested against other insects Tribolium castaneum and Lemna minor. The extract dilutions of the plant caused mortality of the $T$. castaneum, which showed direct proportionalitywith time and concentrations of plant extracts. The maximum mortality percentage was after $72 \mathrm{hrs}$. While, minimum was after 24 hrs. as compared to control. Also, the mortality percentage of the insect increased with the increase in concentration of plant extracts.Phytotoxic activity showed that dilutions of $A$. modesta Wall. extracts significantly inhibited the growth of L.minor.

The obtained result is in agreement with the results of Kundu et al. ${ }^{18}$ and Khani and Asghari ${ }^{19}$.Ahmad et al. ${ }^{20}$ who reported that the crude methanol extract and various fractions were inactive against $T$. minor. Also, methanol extract of A. modesta Wall. was assessed for insecticidal effects against Callosbruchus analis, Rhizopertha dominica and Tribolium castaneum $^{21}$. All test samples exhibited no activity towards $T$. castaneum. While against $R$. dominica, low activity was observed in case of chloroformand n-hexane fractions .Also, other samples were inactive. Significant activity of $60 \%$ was seen with n-hexane fraction against $C$. analis ${ }^{21}$. 
Results of current study showed that the mortality percentage was also directly proportional to concentration. This agrees with the findings of Kunduet al. ${ }^{18}$ who worked on the medicinal plants for insecticidal activity using $T$. castaneum.

It was evident from their results that $A$. modesta Wall. is a potential source of botanical insecticides against adult $C x$. pipiens mosquitoes and $T$. castaneum. Their toxic effects were time and concentration dependent. Phytochemical screening of the aerial parts of the studied plant revealed the presence of carbohydrates and/or glycosides, tannins, flavonoids, unsaturated sterols and/or triterpens as well as saponins.

\section{Conclusion}

Synthetic insecticides are of great threat to the environment due to their toxic effects. Therefore, environment friendly insecticides from natural resources is for greet importance. The present study reveals that $A$. modesta Wall .had good insecticidal properties and can be used as a natural insecticide. The plant extracts could be a new source for pesticides with minimum noxious effects on the environment. Further studies may also lead to isolate and characterize the active compounds of the plant extracts and to elucidate their biological mechanisms of action.

\section{References}

1. Fradin M and Day JF (2002): Insect repellents and mosquito bites: Comparative efficacy of insect repellents against mosquito bites. The New England Journal of Medicine, 347:1.

2. Rajkumar S and Jebanesan A (2005): Larvicidal and Adult Emergence Inhibition Effect of Centella asiatica Brahmi. (Umbelliferae) against Mosquito Culex quinquefasciatus Say. (Diptera: Culicidae), African Journal of Biomedical Research, 8: $31-33$.

3. ICARDA (2015): Managing rangelands: promoting sustainable tree species .http://hdl.handle.net/20.500.11766/338 8

4. Sarwar W (2016): Pharmacological and phytochemical studies on Acacia modesta Wall. ; A review, The Journal of Phytopharmacology, 5(4): 160-166.
5. Gonsalez EE, Delgado J N (1962): Journal of Pharmaceutical Sciences, 51:76.

6. Clauss EP (1961): Pharmacognosy 4th Edition, Henery Kimpton, London, 111.

7. https://link.springer.com/.../bfm\%3A 978-3-642-80530-1\%2F1.pdf.

8. pubs.acs.org/doi/abs/10.1021/ac60178 a040

9. Wall ME, Krider MN, Krewson CF, Eddy CR, William JJ, Corel DS and Centry AS (1954): Journal of American Pharmaceutical Association, 43:1.

10. Walform ML, Morgan $P$ and Benton F (1940): Journal of American Chemical Society, 62: 1484

11. pubs.acs.org/doi/abs/10.1021/ja02073 a014

12. https://www.ncbi.nlm.nih.gov/pmc/ar ticles/PMC2839395/

13. Robinson $T$ (1964): The organic constituents of the higher plants, Burgress Puplishing Co., New York, $2^{\text {nd }}$ Ed.

14. Shellard EJ (1957): Practical plant chemistry.Pitman Medical Puolishing Co., LTD, London.

15. Sharm PP, Pardeshi AB, Vijigiri D (2011): Bioactivity of some medicinal plant extracts against Musca domestica L. Journal of Ecobiotechnology, 9:1416.

16. Khan T, Ahmad M, Khan R, Khan H, Choudhary MI (2008): Phytotoxic and insecticidal activities of medicinal plants of Pakistan, Trichodesma indicum, Aconitum laeve and Sauromatum guttatum. Journal of the Chemical Society of Pakistan, 2: 251255.

17. Nazeefullah S, Dastagir G, Ahmad B (2014): Effect of cold water extracts of Acacia modesta Wall. and Glycyrrhiza glabra Linn. On Tribolium castaneum and Lemna minor. Pakistan Journal of Pharmaceutical Sciences, 2: 217-22.

18. Kundu BR, Ara R, Begum MM, and Sarker ZI (2007): Effect of Bishkatali, Polygonum hydropiper L. plant extracts against the red flour beetle, Tribolium castaneum Herbst. Journal Zoological University Rajshahi, 26: 93-97.

19. Khani $A$ and Asghari J(2012): Insecticide activity of essential oils of 
Phytochemical screening and insecticidal activity of different extracts of Acacia modesta Wall...

Mentha longifolia, Pulicaria gnaphalodes and Achillea wilhelmsii against two stored product pests, the flour beetle, Tribolium castaneum, and the cowpea weevil, Callosobruchus maculatus. Journal of Insect Sciences, 12: 73 .

20. Ahmed B, Ibrar K, Sadiq A, Shumaila B, Jamshaid A, and Farrukh H (2011): Screening of Acacia modesta for haemagglutination, antibacterial, phytotoxic and Insecticidal activities. Journal of Medicinal Plants Research, 14: 30903096.

21. Ahmad B, Khan I, Bashir S, Azam S (2012): Chemical composition and antifungal, phytotoxic, brine shrimp cytotoxicity, insecticidal and antibacterial activities of the essential oils of Acacia modesta. Journal of Medicinal Plants Research, 6: 4653-59. 